\title{
DAYA DUKUNG PERAIRAN UNTUK PENGEMBANGAN BUDIDAYA RUMPUT LAUT Eucheuma cottonii DI KABUPATEN SINJAI, SULAWESI SELATAN
}

\author{
Waluyo $^{1 *}$, Taslim Arifin ${ }^{2}$, Mukti Ali ${ }^{3}$ \\ ${ }^{1}$ Ilmu Kelautan, Politeknik Kelautan dan Perikanan Karawang \\ ${ }^{2}$ Pusat Riset Kelautan_Badan Riset dan Sumberdaya Kelautan dan Perikanan, \\ Kementerian Kelautan dan Perikanan \\ ${ }^{3}$ Fakultas Perikanan Universitas Islam Lamongan \\ *E-mail : waluyo_uyo@yahoo.com
}

\begin{abstract}
ABSTRAK
Pengelolaan sumberdaya perikanan rumput laut jenis Eucheuma cottonii harus dilakukan dengan memperhatikan daya dukung perairan (waters carrying capacity) dengan tujuan untuk menentukan kapasitas optimum budidaya rumput laut. Pendekatan yang dapat digunakan untuk menentukan daya dukung adalah dengan analisis ecological footprint $(E F)$, dimana pada penelitian ini adalah footprint produksi. Penelitian ini dilakukan pada Oktober 2016 untuk memetakan dan menganalisis daya dukung perairan di Kabupaten Sinjai, Sulawesi Selatan dengan sistem informasi geografis dan pendekatan ecological footprint. Berdasarkan hasil analisis daya dukung perairan di Kabupaten Sinjai menunjukkan bahwa tingkat pemanfaatan perairan $\left(\mathrm{EF}_{\mathrm{P}}\right)$ adalah 4.68 ton/kapita/tahun atau setara dengan 6,223.49 ton/tahun, sedangkan ketersediaan ruang perairan (biocapacity/BC) adalah 32,607.28 hektar yang mampu untuk memproduksi rumput laut sebanyak 483,446.09 ton/tahun. Apabila menggunakan asumsi bahwa pemanfaatan seluruh ketersediaan lahan perairan yang ada $(32,607,28$ hektar), maka daya dukung jumlah sumberdaya manusia yang mungkin untuk dapat memanfaatkan lahan tersebut adalah 10,839 kapita.
\end{abstract}

Kata kunci : budidaya rumput laut, ecological footprint, biocapacity, daya dukung perairan, Sinjai

\section{PENDAHULUAN}

Budidaya rumput laut sangat berkembang di beberapa daerah di wilayah Provinsi Sulawesi Selatan. Hingga saat ini, lahan budidaya laut seluas 193.700 hektare, sedangkan lahan budidaya tambak untuk budidaya rumput laut sekitar 32.000 hektare, dari potensi 98.617 hektare (DKP provinsi Sulsel 2015). Selanjutnya berdasarkan DKP Kabupaten Sulawesi Selatan menyatakan bahwa laju pertumbuhan produksi perikanan budidaya, khususnya pada komoditi rumput laut mengalami perkembangan yang signifikan. Pada tahun 2016, jumlah produksi rumput laut lebih dari 3 juta ton, dengan jenis yang berbeda-beda, yaitu Gracillaria sp, E. Spinosum, E. Cottonii dengan nilai produksi Rp. 3,9 Triliun. Volume ekspor rumput laut pada tahun 2016 mencapai 105.127 ton dengan nilai ekspor US\$ 85,9 juta.

Pusat produksi rumput laut di Sulawesi Selatan tersebar di beberapa kabupaten diantaranya adalah Kabupaten Selayar, Sinjai, Bulukumba, Bantaeng, Jeneponto, Takalar, Makassar, Pangkep, Barru, Pinrang, Bone, Wajo, Palopo, Luwu, Luwu Utara dan Luwu Timur.

Berdasarkan data perkembangan produksi komoditi unggulan Dinas Kelautan dan Perikanan Provinsi Sulawesi Selatan tahun 2016 menyatakan bahwa produksi rumput laut Sulawesi Selatan mencapai 3.401.752,5 ton atau sekitar 30,2 persen dari produksi nasional. Sedangkan untuk produksi Bandeng mencapai 127.434,1 ton atau sekitar 18,9\% dari produksi rumput laut nasional.

Penelitian ini bertujuan untuk mengetahui daya dukung perairan di Kabupaten Sinjai, Sulawesi selatan untuk budidaya rumput laut jenis Eucheuma cottonii dengan pendekatan analisis sistem informasi geografis dan ecological footprint. 


\section{METODOLOGI}

\section{Waktu dan Lokasi Penelitian}

Penelitian dilaksanakan pada bulan Oktober 2016 di perairan Kabupaten Sinjai, Sulawesi Selatan dan pengambilan data primer dilakukan pada 20 titik stasiun. Peta lokasi penelitian ditampilkan pada Gambar 1.

\section{Data}

Data primer perairan yang diambil dan dianalisis secara insitu meliputi suhu air laut, salinitas, $\mathrm{pH}$, oksigen terlarut dan arus. Data suhu dan oksigen terlarut diukur menggunakan DO meter, salinitas menggunakan refraktometer, $\mathrm{pH}$ menggunakan $\mathrm{pH}$ meter dan arus menggunakan current meter dan dari data HyCom + NCODA bulan Oktober 2016. Data sekunder pasang surut berasal dari Badan Informasi Geografis (BIG) tahun 2016.

Data yang dianalisis di laboratorium Balai Penelitian dan Pengembangan Budidaya Air Payau, Maros, Sulawesi Selatan meliputi data total suspended solid
(TSS), chemical oxygen demand (COD), nitrat, fosfat, amoniak, dan clorofil-a. Semua data perairan tersebut diambil menggunakan botol niskin pada kedalaman 2 meter.

\section{Analisis Data}

Analisis data dilakukan untuk mengetahui daya dukung perairan yang dapat dimanfaatkan untuk kegiatan budidaya rumput laut. Daya dukung perairan meliputi 3 komponen utama yang harus diketahui, yaitu : 1). Berapa besar tingkat pemanfaatan perairan (dalam hal ini adalah Ecological Footprint Produksi / $\left.\mathrm{EF}_{\mathrm{P}}\right), 2$ 2). Berapa besar ketersediaan perairan (Biocapacity / BC) yang mampu untuk mendukung kegiatan tersebut, serta, 3). Berapa banyak jumlah sumberdaya manusia yang memungkinkan untuk memanfaatkan ketersediaan ruang perairan yang ada. Dengan membandingkan antara Biocapacity terhadap Ecological Footprint, maka akan menghasilkan berapa besar daya dukung perairan.

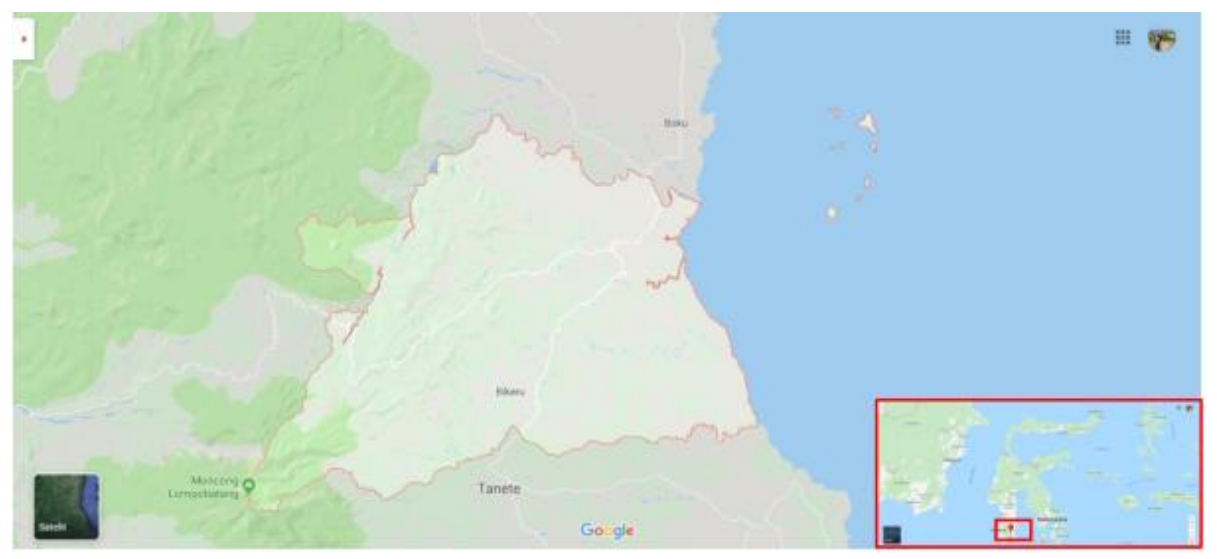

Gambar 1. Peta lokasi penelitian.

\section{Analisis Pemanfaatan Ruang Perairan}

Analisis pemanfaatan ruang perairan pada penelitian ini adalah analisis Ecological Footprint Produksi (EFP) yang didasarkan pada tingkat produksi rumput laut terhadap jumlah pembudidaya, dengan persamaan sebagai berikut (Ewing et al., 2010):

$$
E F_{P}=\frac{P}{Y_{N}}
$$

Keterangan :

$\mathrm{EF}_{\mathrm{p}} \quad$ : Ecological Footprint Produksi rumput laut (ton/kapita)

P : Produksi rumput laut (ton) 
$\mathrm{Y}_{\mathrm{N}} \quad$ : Jumlah Pembudidaya (kapita)

Analisis Ketersediaan Ruang Perairan

Analisis ketersediaan ruang perairan (biocapacity) didasarkan pada kesesuaian perairan untuk mendukung budidaya rumput laut. Konsep ini berdasarkan pada parameter fisika, kimia dan biologi perairan yang secara ekologis merupakan prasyarat kelayakan dalam budidaya rumput laut. Untuk itu digunakan teknik Sistem Informasi Geografis (SIG) untuk mengetahui luas perairan yang sesuai untuk budidaya rumput laut. Berdasarkan kategori kelas kesesuaian budidaya rumput laut, maka digunakan untuk menghitung biocapacity (kemampuan luas perairan yang tersedia) dengan rumus sebagai berikut (Bala and Hossain, 2009):

\section{Biocapacity = Luas kesesuaian lahan $x$ faktor yield}

Keterangan :

Biocapacity : Kemampuan perairan memproduksi rumput laut (ton)

Luas : Luas lahan berdasarkan kesesuaian (hektar)

Faktor yield : Produktivitas rumput laut lokal (ton/hektar)

\section{Daya Dukung Perairan}

Daya dukung perairan merupakan kemampuan sebuah sistem untuk mendukung kegiatan pada tingkat tertentu, dalam hal ini adalah kegiatan budidaya rumput laut jenis Eucheuma cottonii. Daya dukung terkait dengan sistem wilayah pesisir yang memiliki batas-batas tertentu atau memiliki ambang batas terhadap suatu kegiatan. Perhitungan daya dukung perairan pada penelitian ini menggunakan 2 pendekatan, yaitu daya dukung berdasarkan analisis Ecological Footprint (EF).

Untuk mengetahui daya dukung suatu perairan berdasarkan analisis Ecological
Footprint (EF), terdapat 3 (tiga) komponen utama yang harus diketahui, yaitu : 1) seberapa besar tingkat pemanfaatan ruang perairan (dalam hal ini adalah Ecological Footprint Produksi/EFP), 2) seberapa besar ketersediaan ruang perairan yang mampu untuk mendukung kegiatan tersebut (Biocapacity/BC), serta, 3) berapa banyak jumlah sumberdaya manusia yang memungkinkan untuk memanfaatkan ketersediaan ruang perairan yang ada. Dengan membandingan antara Biocapacity terhadap Ecological Footprint maka akan menghasilkan seberapa besar tingkat daya dukung perairan. Persamaan untuk menghitung daya dukung adalah sebagai berikut (Yonvitner $d k k$. 2007) :

$$
C C=\frac{B C}{E F_{P}}
$$

Keterangan :

$$
\begin{array}{ll}
\mathrm{CC} & \text { : Carrying Capacity (kapita) } \\
\mathrm{BC} & \text { : Biocapacity (ton) } \\
\mathrm{EFP} & : \text { Ecological Footprint Produksi } \\
& \text { (ton/kapita) }
\end{array}
$$

\section{HASIL DAN PEMBAHASAN}

\section{Kesesuaian Perairan untuk Rumput Laut}

Analisis pemetaan kesesuaian lahan perairan untuk budidaya rumput laut jenis Eucheuma cottonii di Kabupaten Sinjai dilakukan overlay dari beberapa parameter oseanografi. Akan tetapi sebelum melakukan overlay, terlebih dahulu dilakukan skoring dan pembobotan dari setiap parameter tersebut untuk setiap kriteria kesesuaian. Selanjutnya dilakukan overlay dari setiap parameter tersebut untuk mendapatkan peta kesesuaian ruang perairan dengan menggunakan software Arc.GIS versi 10 .

Berdasarkan hasil analisis kesesuaian, maka luas kesesusian perairan di Kabupaten Sinjai pada bulan Oktober 2016 (musim peralihan 2) dengan kategori sangat sesuai (S1) seluas 4.167,91 hektar, kategori sesuai (S2) 28.439,37 hektar dan 
tidak sesuai (N) 11.168,68 hektar. Apabila dengan asumsi kategori sangat sesuai (S1) dan sesuai (S2) digabungkan menjadi perairan yang layak dan sesuai untuk budidaya rumput laut, maka total luas yang layak dan sesuai adalah 32.607,28 hektar.

Berdasarkan hasil analisis kesesuaian perairan untuk budidaya rumput laut Eucheuma cottonii di Kabupaten Sinjai, maka secara umum lokasi perairan yang masuk kategori sangat sesuai (S1) terdapat di sepanjang perairan pesisir dekat pantai Kabupaten Sinjai dan di sekitar perairan Kecamatan Pulau Sembilan. Sedangkan lokasi perairan dengan kategori sesuai terletak di pertengahan antara daerah pesisir dekat pantai sampai sebelum ke perairan di Kecamatan Pulau Sembilan. Kategori perairan tidak sesuai untuk budidaya rumput laut Eucheuma cottonii berada di laut lepas hingga batas 4 mill laut. Apabila berdasarkan hasil pemetaan kesesuaian perairan untuk budidaya rumput laut Eucheuma cottonii, maka secara umum perairan Kabupaten Sinjai didominasi oleh perairan dengan kategori sesuai (S2).

Perairan di Kabupaten Sinjai di sepanjang pantai sampai sejauh kurang lebih 1 mill sangat sesuai untuk budidaya rumput laut. Disamping dipengaruhi oleh beberapa parameter oseanografi, juga yang mudah untuk dipahami adalah kedalaman perairan yang relatif dangkal yaitu sekitar 5 - 20 meter, mudah untuk dijangkau oleh para pembudidaya serta kekuatan arus yang cukup tenang. Kedalaman perairan mulai batas 1 mill hingga 3,5 mill mencapai kurang lebih 30 meter, sehingga disamping kurang efektif dijangkau oleh pembudidaya, juga sangat memungkinkan kekuatan arus yang tinggi, sehingga dapat mengakibatkan ketidakstabilan rangkaian tali ris rumput laut hingga menyebabkan kerusakan akibat terbawa arus permukaan yang cukup tinggi. Kedalaman perairan hingga mencapai 30 meter akan membutuhkan tali jangkar rumput laut yang cukup panjang, sehingga usaha tersebut akan kurang efektif. Selain itu, jarak efektif untuk mencapai lokasi budidaya sangat mempengaruhi tingkat kesesuaian perairan. Apabila jarak lokasi budidaya cukup jauh dari pantai hingga mencapai 2-4 mill akan membutuhkan waktu, tenaga dan bahan bakar untuk perahu yang cukup besar, sehingga dalam proses mengontrol area budidaya rumput laut serta pengangkutan hasil panen tidak akan efektif.

Matrik kesesuaian untuk budidaya rumput laut Eucheuma cottonii ditampilkan pada Tabel 1, sedangkan luasan kesesuaian perairan untuk budidaya rumput laut ditampilkan pada Tabel 2. Peta kesesuaian perairan budidaya rumput laut disajikan pada Gambar 2. Sedangkan perbandingan luas lahan eksisting dan luas kesesuaian perairan ditampilkan pada Gambar 3.

Tabel 1. Matrik kesesuaian rumput laut Eecheuma cottonii

\begin{tabular}{|c|c|c|c|c|c|c|c|}
\hline No & Parameter & Satuan & Kesesuaian & Kisaran & Skor & Bobot $(\%)$ & Nilai total \\
\hline \multirow[t]{3}{*}{1} & Fosfat & $\overline{\mathrm{mg} / \mathrm{l}}$ & S1 & $0,2-0,5$ & 30 & & $\overline{420}$ \\
\hline & & & $\mathrm{S} 2$ & $0,1-0,2 \& 0,5-1$ & 20 & 8 & 280 \\
\hline & & & $\mathrm{N}$ & $<0,1 \&>1$ & 10 & & 140 \\
\hline \multirow[t]{3}{*}{2} & Nitrat & $\mathrm{mg} / \mathrm{l}$ & S1 & $0,9-3,2$ & 30 & & 420 \\
\hline & & & $\mathrm{S} 2$ & $0,1-<0,9 \& 3,3-3,4$ & 20 & 10 & 280 \\
\hline & & & $\mathrm{N}$ & $<0,1 \&>3,4$ & 10 & & 140 \\
\hline \multirow[t]{3}{*}{3} & Amoniak & $\mathrm{mg} / \mathrm{l}$ & S1 & $<0,3$ & 30 & & 150 \\
\hline & & & $\mathrm{S} 2$ & $0,3-0,5$ & 20 & 5 & 100 \\
\hline & & & $\mathrm{N}$ & $>0,5$ & 10 & & 50 \\
\hline \multirow[t]{3}{*}{3} & Arus & $\mathrm{m} / \mathrm{s}$ & $\mathrm{S} 1$ & $0,2-0,3$ & 30 & & 300 \\
\hline & & & $\mathrm{S} 2$ & $0,1-0,2 \& 0,3-0,4$ & 20 & 10 & 200 \\
\hline & & & $\mathrm{N}$ & $<0,1 \&>0,4$ & 10 & & 100 \\
\hline
\end{tabular}




\begin{tabular}{|c|c|c|c|c|c|c|c|}
\hline No & Parameter & Satuan & Kesesuaian & Kisaran & Skor & Bobot (\%) & Nilai total \\
\hline \multirow[t]{3}{*}{4} & Suhu & ${ }^{\circ} \mathrm{C}$ & S1 & $24-30$ & 30 & & 240 \\
\hline & & & S2 & $20-24$ & 20 & 8 & 160 \\
\hline & & & $\mathrm{N}$ & $<20 \&>30$ & 10 & & 80 \\
\hline \multirow[t]{3}{*}{5} & Salinitas & $\%$ & S1 & $30-32$ & 30 & & 390 \\
\hline & & & S2 & $22-30 \& 32-34$ & 20 & 12 & 260 \\
\hline & & & $\mathrm{N}$ & $<22 \&>34$ & 10 & & 130 \\
\hline \multirow[t]{3}{*}{6} & $\mathrm{pH}$ & & S1 & $6,5-8,5$ & 30 & & 240 \\
\hline & & & S2 & $4-6,5 \& 8,5-9,5$ & 20 & 5 & 160 \\
\hline & & & $\mathrm{N}$ & $<4 \&>9,5$ & 10 & & 80 \\
\hline \multirow[t]{3}{*}{7} & DO & $\mathrm{mg} / \mathrm{l}$ & S1 & $>6$ & 30 & & 150 \\
\hline & & & S2 & $4-6$ & 20 & 5 & 100 \\
\hline & & & $\mathrm{N}$ & $<4$ & 10 & & 50 \\
\hline \multirow[t]{3}{*}{8} & COD & $\mathrm{mg} / \mathrm{l}$ & S1 & $10-90$ & 30 & & 150 \\
\hline & & & $\mathrm{S} 2$ & $91-100$ & 20 & 3 & 100 \\
\hline & & & $\mathrm{N}$ & $>100$ & 10 & & 50 \\
\hline \multirow[t]{3}{*}{9} & Clorofil-a & $\mathrm{mg} / \mathrm{l}$ & S1 & $3,5-10$ & 30 & & 150 \\
\hline & & & S2 & $0,2-<3,5$ & 20 & 2 & 100 \\
\hline & & & $\mathrm{N}$ & $<0,2$ & 10 & & 50 \\
\hline \multirow[t]{3}{*}{10} & Kekeruhan & NTU & S1 & $\leq 10$ & 30 & & 240 \\
\hline & & & S2 & $<10-<40$ & 20 & 7 & 160 \\
\hline & & & $\mathrm{N}$ & $>40$ & 10 & & 80 \\
\hline \multirow[t]{3}{*}{11} & Jarak dari pantai & $\mathrm{m}$ & S1 & $150-1500$ & 30 & & 150 \\
\hline & & & S2 & $1200-2000$ & 20 & 5 & 100 \\
\hline & & & $\mathrm{N}$ & $>2000$ & 10 & & 50 \\
\hline \multirow[t]{3}{*}{12} & Kedalaman & $\mathrm{m}$ & S1 & $2-15$ & 30 & & 420 \\
\hline & & & S2 & $16-20$ & 20 & 14 & 280 \\
\hline & & & $\mathrm{N}$ & $>20$ & 10 & & 140 \\
\hline$\overline{\text { Total }}$ & & & & & & 100 & \\
\hline
\end{tabular}

Keterangan : Skor berdasarkan Prahasta (2002), bobot berdasarkan pertimbangan pengaruh variable dominan

Tabel 2. Kesesuaian ruang perairan untuk rumput laut Eecheuma cottonii

\begin{tabular}{clr}
\hline No & Kriteria & \multicolumn{2}{c}{ Luas (hektar) } \\
\hline 1 & Sangat sesuai (S1) & $4.167,91$ \\
2 & Sesuai (S2) & $28.439,37$ \\
3 & Tidak sesuai (N) & $11.168,65$ \\
\hline & Total (S1 + S2) & $32.607,28$ \\
\hline
\end{tabular}

\section{Pemanfaatan Ruang Perairan}

Analisis pemanfaatan ruang perairan untuk budidaya rumput laut di Kabupaten Sinjai dilakukan dengan pendekatan ecological footprint. Analisis ecological footprint (EF) adalah analisis yang menyatakan suatu daerah ekologis yang produktif untuk memberikan sumber daya laut sebagai pasokan konsumsi bagi penduduk di daerah yang bersangkutan (Adrianto 2010). Dengan kata lain, analisis ecological footprint adalah total area yang dibutuhkan untuk mendukung suatu populasi dan atau kegiatan tertentu. Analisis EF juga dapat menentukan berapa besar sumberdaya yang dapat diproduksi (ecological footprint productions/EFP) terhadap luas lahan yang tersedia.Analisis EF pada penelitian ini adalah analisis ecological footprint produksi ( $\mathrm{EF}$ ) yang menggambarkan jumlah total sumberdaya yang diproduksi (produksi rumput laut Eucheuma cottonii) terhadap lahan eksisting yang ada.

Produksi rumput laut Eucheuma cottonii di Kabupaten Sinjai mulai tahun 2008-2015 cenderung mengalami peningkatan, begitu juga dengan jumlah nelayan pembudidaya di wilayah tersebut.Berdasarkan data produksi dan jumlah pembudidaya, maka akan dapat dihitung $\mathrm{EFP}_{\mathrm{P}}$ masing-masing daerah tersebut. 
Nilai $\mathrm{EF}_{\mathrm{P}}$ rumput laut di Kabupaten Luwu menunjukkan bahwa perairan dengan rata-rata luas pemanfaatan eksisting 436 hektar dan dimanfaatkan oleh pembudidaya rumput laut sebanyak
1.280 kapita, maka perairan tersebut mampu menghasilkan produksi rumput laut $\left(\mathrm{EF}_{\mathrm{P}}\right)$ sebanyak 4,68 ton/kapita/tahun. Hasil analisis $E F P$ di Kabupaten Sinjai disajikan pada Tabel 3 .
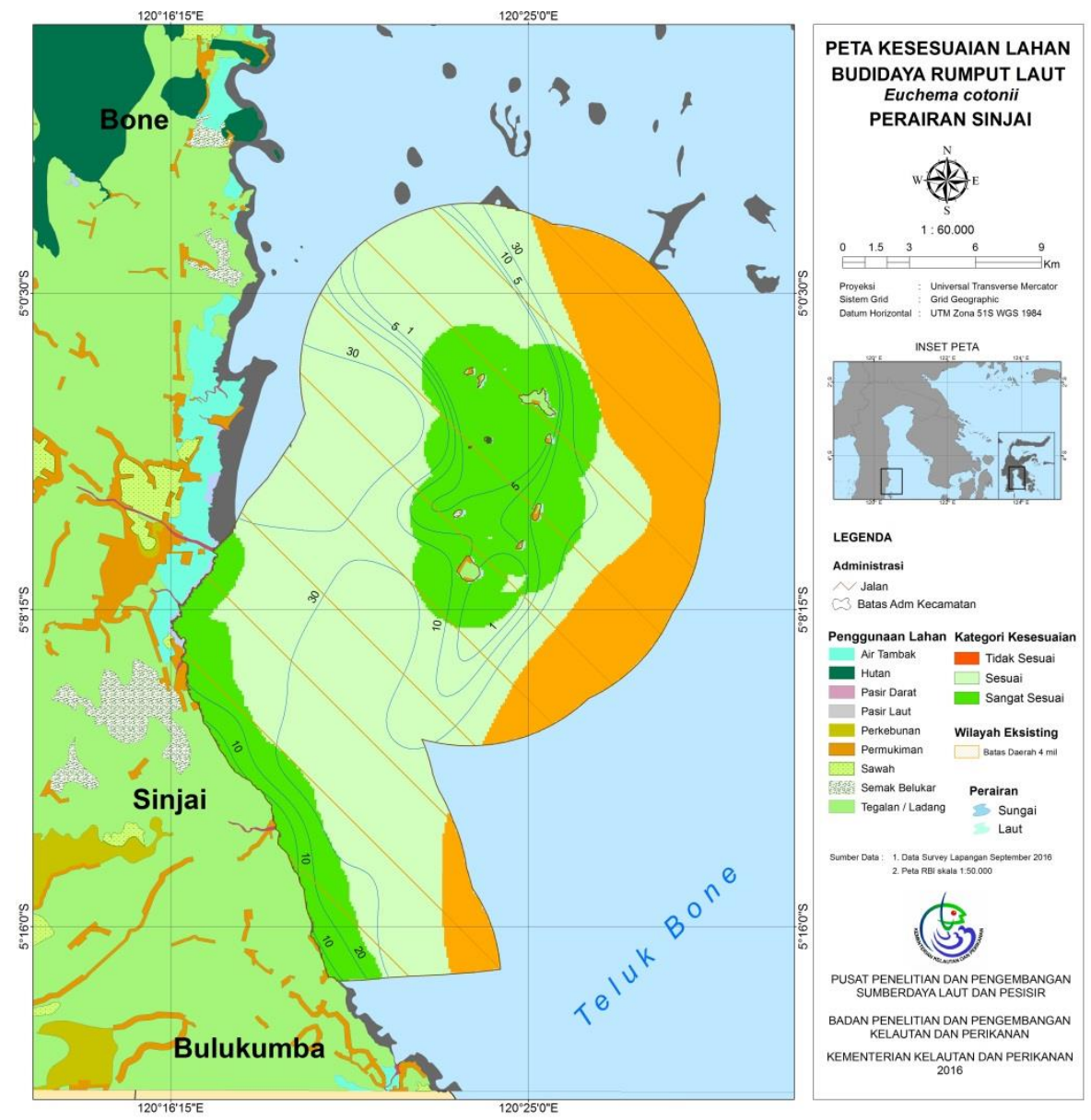

Gambar 2. Peta kesesuaian perairan untuk rumput laut eucheuma cottonii di Kabupaten Sinjai

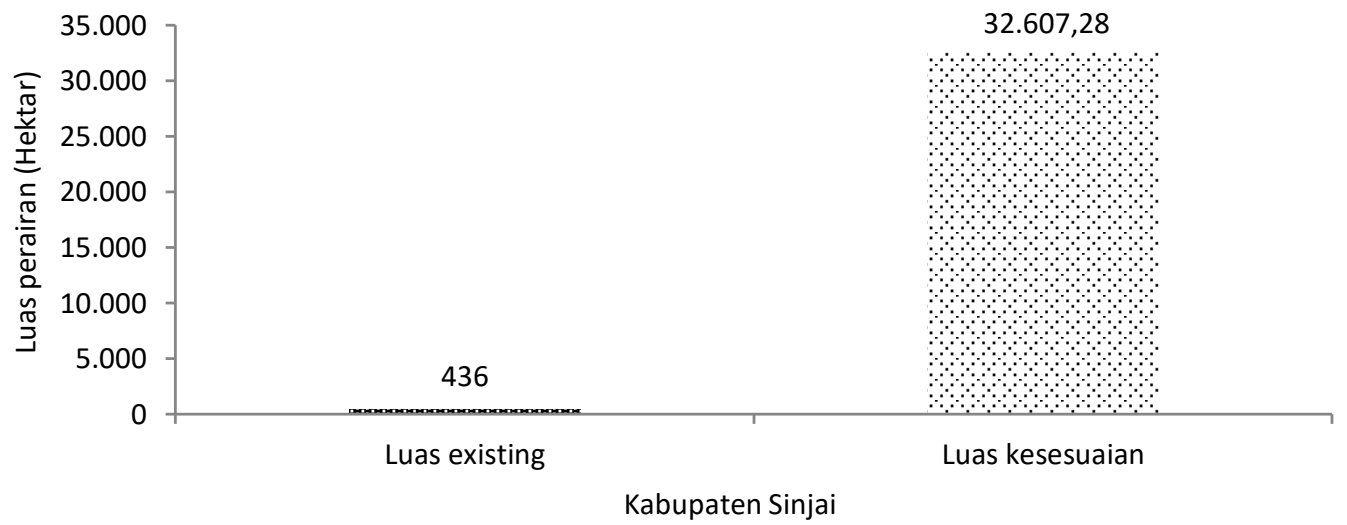

Gambar 3. Perbandingan luas lahan perairan eksisting dengan luas kesesuaian perairan di Kabupaten Sinjai 


\section{Ketersediaan Ruang Perairan (Biocapacity)}

Ketersediaan ruang perairan (biocapacity/BC) untuk budidaya rumput laut Eucheuma cottonii di Kabupaten Sinjai akan menggambarkan 2 komponen utama, yaitu 1) seberapa luas keseluruhan suatu perairan tersebut yang mampu untuk mendukung budidaya rumput laut, serta, 2) seberapa besar produk rumput laut yang bisa dicapai (dengan asumsi pemakaian keseluruhan terhadap ketersediaan lahan yang ada).

Analisis biocapacity didasarkan pada kesesuaian perairan yang mendukung budidaya rumput laut. Kesesuaian ruang perairan yang dapat dimanfaatkan untuk budidaya rumput laut secara spasial menggunakan konsep evaluasi kesesuaian lahan. Konsep ini berdasarkan pada parameter fisika, kimia dan biologi perairan yang secara ekologis merupakan prasyarat kelayakan dalam budidaya rumput laut, dengan menggunakan teknik sistem informasi geografis (SIG) untuk mengetahui luas perairan yang sesuai untuk budidaya rumput laut di Kabupaten Sinjai. Secara spasial, perairan Kabupaten
Sinjai untuk pengembangan rumput laut Eucheuma cottonii di kelompok dalam 3 kategori yaitu kelas sangat sesuai (S1), sesuai (S2) dan tidak sesuai (N). Perhitungan biocapacity pada penelitian ini membagi menjadi biocapacity parsial (berdasarkan masing-masing kategori kelas S1 dan S2) serta biocapacity total (total luas lahan perairan dari kategori kelas S1 dan S2).

Berdasarkan analisis biocapacity perairan Kabupaten Sinjai, maka didapatkan hasil bahwa perairan dengan kategori sangat sesuai (S1) dapat menghasilkan rumput laut rata-rata sebesar 61.794,78 ton/tahun dan kategori sesuai (S2) sebesar 421.651,31 ton/tahun. Apabila dengan asumsi kategori S1 dan S2 digabungkan maka biocapacity total bisa mencapai 483.446,09 ton/tahun yang artinya bahwa apabila dengan asumsi pemanfaatan seluruh lahan yang tersedia seluas 32.607,28 hektar, maka perairan tersebut mampu untuk menghasilkan produksi rumput laut sebanyak 483.446,09 ton/tahun. Hasil analisis biocapacity perairan Kabupaten Sinjai ditampilkan pada Tabel 4 dan Gambar 4.

Tabel 3. Ecological footprint produksi rumput laut Eecheuma cottonii di Kabupaten Sinjai

\begin{tabular}{ccrrr}
\hline No & Tahun & Pembudidaya (Kapita) & Produksi (Ton) & $\mathrm{EF}_{\mathrm{p}}$ (Ton/Kapita/Tahun) \\
\hline 1 & 2008 & 379 & $1.873,21$ & 4,94 \\
2 & 2009 & 1.155 & $1.942,00$ & 1,68 \\
3 & 2010 & 1.259 & $5.464,16$ & 4,02 \\
4 & 2011 & 810 & $3.176,58$ & 3,92 \\
5 & 2012 & 1.521 & $8.720,00$ & 5,73 \\
6 & 2013 & 1.644 & $8.820,00$ & 5,36 \\
7 & 2014 & 1.676 & $12.112,00$ & 7,23 \\
8 & 2015 & 1.698 & $7.680,00$ & 4,52 \\
\hline \multicolumn{5}{c}{ Rata-rata } \\
\hline
\end{tabular}

\section{Daya Dukung Perairan}

Daya dukung perairan merupakan kemampuan sebuah sistem untuk mendukung kegiatan pada tingkat tertentu (UNEP 1996), dalam hal ini adalah kegiatan budidaya rumput laut jenis Eucheuma cottonii. Dengan kata lain, daya dukung terkait dengan sistem wilayah pesisir yang memiliki batas-batas tertentu atau memiliki ambang batas terhadap suatu kegiatan (MacLeod dan Cooper 2005).

Daya dukung suatu perairan berdasarkan analisis ecological footprint (EF) dapat dihitung dengan mengetahui tiga komponen utama, yaitu : 1). Berapa besar tingkat pemanfaatan perairan (dalam 
hal ini adalah ecological footprint produksi $\left(\mathrm{EF}_{\mathrm{P}}\right)$, 2). Berapa besar ketersediaan ruang perairan (biocapacity / BC) yang mampu untuk mendukung kegiatan tersebut, serta, 3). Berapa banyak jumlah sumberdaya manusia (kapita) yang memungkinkan untuk memanfaatkan ketersediaan ruang perairan yang ada. Perbandingan antara biocapacity terhadap ecological footprint maka akan menghasilkan berapa besar daya dukung perairan.

Berdasarkan hasil analisis daya dukung perairan di Kabupaten Sinjai menunjukkan bahwa tingkat pemanfaatan perairan $\left(\mathrm{EF}_{\mathrm{P}}\right)$ adalah 4,68 ton/kapita/tahun atau setara dengan 6.223,49 ton/tahun, sedangkan ketersediaan ruang perairan (biocapacity/BC) adalah 32.607,28 hektar yang mampu untuk memproduksi rumput laut sebanyak 483.446,09 ton/tahun. Apabila menggunakan asumsi bahwa pemanfaatan seluruh ketersediaan lahan perairan yang ada (32.607,28 hektar), maka daya dukung jumlah sumberdaya manusia yang mungkin untuk dapat memanfaatkan lahan tersebut adalah 10.839 kapita.

Tabel 4. Biocapacity perairan untuk Eecheuma cottonii di Kabupaten Sinjai

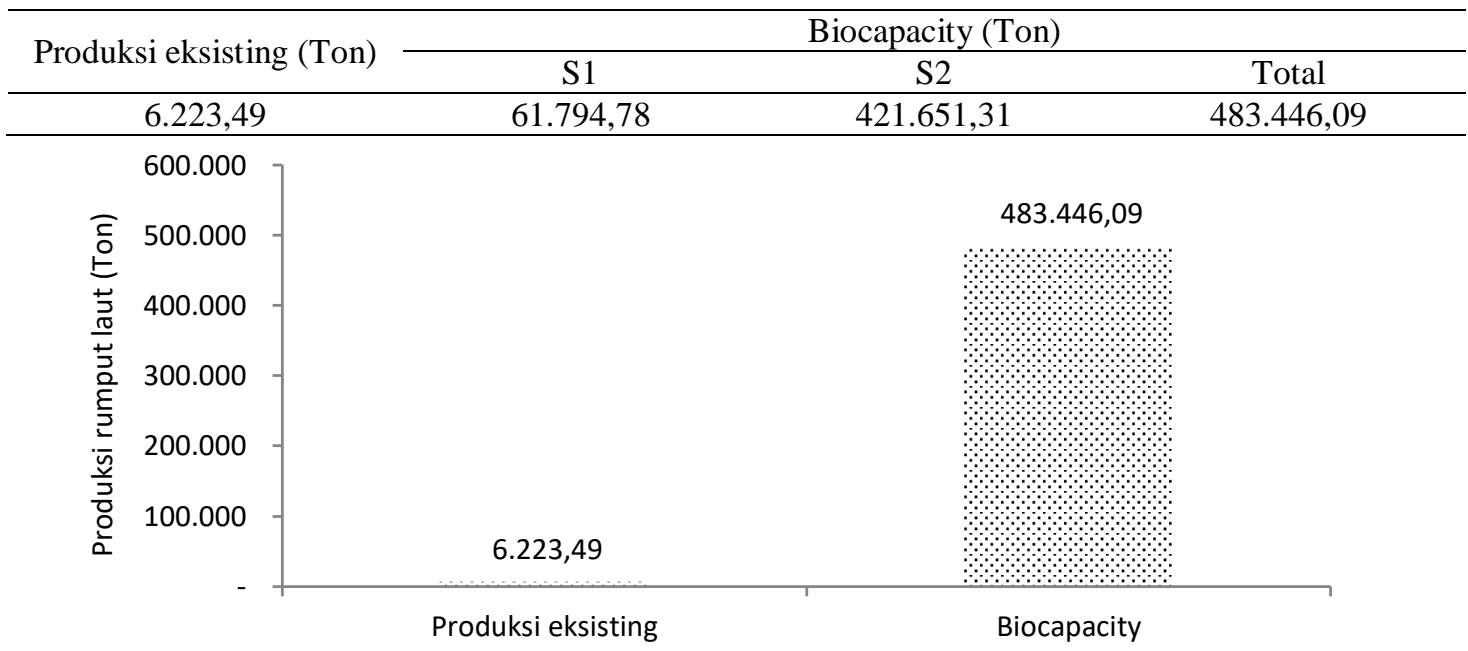

Gambar 4. Perbandingan produksi rumput laut eksisting dengan biocapacity perairan di Kabupaten Sinjai

\section{KESIMPULAN}

Berdasarkan hasil analisis kesesuaian, maka luas kesesusian perairan di Kabupaten Sinjai pada bulan Oktober 2016 (musim peralihan 2) dengan kategori sangat sesuai (S1) seluas 4.167,91 hektar, kategori sesuai (S2) 28.439,37 hektar dan tidak sesuai (N) 11.168,68 hektar. Apabila dengan asumsi kategori sangat sesuai (S1) dan sesuai (S2) digabungkan menjadi perairan yang layak dan sesuai untuk budidaya rumput laut, maka total luas yang layak dan sesuai adalah 32.607,28 hektar.

Berdasarkan hasil analisis daya dukung perairan di Kabupaten Sinjai menunjukkan bahwa tingkat pemanfaatan perairan $\left(\mathrm{EF}_{\mathrm{P}}\right)$ adalah 4.68 ton/kapita/tahun atau setara dengan 6,223.49 ton/tahun, sedangkan ketersediaan ruang perairan (biocapacity/BC) adalah 32,607.28 hektar yang mampu untuk memproduksi rumput laut sebanyak 483,446.09 ton/tahun. Apabila menggunakan asumsi bahwa pemanfaatan seluruh ketersediaan lahan perairan yang ada $(32,607,28$ hektar $)$, maka daya dukung jumlah sumberdaya manusia yang mungkin untuk dapat memanfaatkan lahan tersebut adalah 10,839 kapita. 


\section{DAFTAR PUSTAKA}

Adipu, Y.,C. Lumenta, E. Kaligis, dan H.J. Sinjal. 2013. Kesesuaian lahan budidaya laut di perairan Kabupaten Boolang Mongondow Selatan, Sulawesi Utara. $J$. Perikanan dan Kelautan Tropis, 9(1):19-26

Adrianto, L. 2010. Fishery resources appropriation as sustainability indicator: An ecological footprint approach. Bogor. PKSPL IPB. $2 \mathrm{Hlm}$.

[AMWQ] ASEAN Marine Water Quality. 2008. Management guidelines and nonitoring manual. Jakarta. The ASEAN Secretariat. 146p.

Anonim. 2002. Modul sosialisasi dan orientasi penataan ruang, laut, pesisir dan pulau-pulau kecil. Jakarta. Ditjen Pesisir dan PulauPulau Kecil. Direktorat Tata Ruang Laut, Pesisir dan Pulau-pulau Kecil.

Arianti, R.W., L. Sya'rani, dan E. Arini. 2007. Analisis kesesuaian perairan pulau karimunjawa dan pulau kemujan sebagai lahan budidaya rumput laut menggunakan Sistem Informasi Geografis. J. Pasir Laut, $3(1): 27-45$.

Aslan LM. 1998. Budidaya Rumput Laut. Yokyakarta: Kanisius. 11-19Hlm.

Bala, B.K. and Md. A. Hossain. 2009. Integrated management of coastal zone for food security. Final Report. Bangladesh. Department of Farm Power and Machinery, Bangladesh Agricultural University. 19p.

Bastianoni, S., V. Niccolucci, E. Neri, G. Cranston, A. Galli, and M.
Wackernagel. 2013. Sustainable Development: Ecological Footprint in Accounting. In Encyclopedia of Environmental Management. New York: Taylor and Francis, (2013):2467-2481.

Dahuri, R.1998. The application of carryng capacity concept for sustainable costal resources development in Indonesia.J. Pengelolaan Sumber Daya Pesisir dan Lautan Indonesia, 1(1): 22-31.

Ding, L., Y. Ma, B. Huang, and S. Chen. 2013. Effects of seawater salinity and temperature on growth and pigment contents in Hypnea cervicornis J. agardh (Gigartinales, Rhodophyta). (Lin H, Ed). Hindawi Publishing Corporation. J.BioMed Research International, 2013, 10

[DKP] Dinas Kelautan dan Perikanan Kabupaten Sinjai. 2016. Laporan tahunan perikanan Kabupaten Sinjai Tahun 2016. Belopa. DKP Kab. Luwu. 31Hlm.

[DKP] Dinas Kelautan dan Perikanan Provinsi Sulawesi Selatan. 2015. Laporan tahunan DKP Provinsi Sulawesi Selatan 2015. Palopo. DKP Kota Palopo. 42Hlm.

Ewing, B., A. Reed, A. Galli, J. Kitzes, and M. Wackernagel. 2010. Calculation Methodology for the National Footprint Accounts. 2010 Edition. Oakland: Global Footprint Network. 3p.

Gazali, I. 2013. Evaluasi dampak pembuangan limbah cair pabrik kertas terhadap kualitas air Sungai Klinter Kabupaten Nganjuk. $J$. Keteknikan Pertanian Tropis dan Biosistem, 1(2):1-8 
Glenn, E.P. and M.S. Doty. 1981. Photosynthesis and respiration of the tropical red seaweeds, Eucheuma striatum (Tambalang and Elkhorn varieties) and E. denticulatum. J.Aquatic Botany, 10:353-364.

Harrison, P.J. and C.L. Hurd. 2001. Nutrient physiology of seaweeds: Application of concepts to aquaculture. J. Cahiers de Biologie Marine, 42:71-82.

Hayashi, L.,G.S.M. Faria, B.G. Nunes, C.S. Zitta, L.A. Scariot,T. Rover, M.R.L. Felix, and Z.L. Bouzon. 2010. Effects of salinity on the growth rate, carrageenan yield, and cellular structure of Kappaphycus alvarezii (Rhodophyta, Gigartinales) cultured in vitro. $J$. Appl Phycol, 23(3):439-447

Hurd, C.L., P.J. Harrison, K. Bischof, and C.S. Lobban. 2014. Seaweed ecology and physiology. $2^{\text {nd }} e d$. Cambridge. Cambridge University Press. 238 p, 349 p.

Kementerian Lingkungan Hidup. 1988. Keputusan Menteri Negara Kependudukan dan Lingkungan Hidup Nomor 02 Tahun 1988 tentang Pedoman Penetapan Baku Mutu Lingkungan. Jakarta.

Mairh, O.P., S.T. Zodape, A. Tewari, and M.R.Rajyaguru. 1995. Culture of marine red alga Kappaphycus Striatum (Schmitz) Doty on the Saurashtra Region, West Coast of India. Indian. J. Mar Sci, 24:24-31.

MacLeod, M. and J.A.G. Cooper. 2005. Carrying capacity in coastal areas. Encyclopedia of Coastal Science. Springer. Schwartz M. (Ed.). 226p.
[PHILMINAQ] Mitigating Impact from Aquaculture in the Philippines. Annex 2. 2006. Water quality criteria and standards for freshwater and marine aquaculture. <URL:http://www.aquaculture.asia/ files/PMNQ\%20

WQ\%20standard\%202.pdf.

[Accessed 20 December 2015].6$18 \mathrm{pp}$.

Prahasta, E. 2002. Konsep - konsep dasar Sistem Informasi Geografis. Bandung. CV Informatika. 57Hlm.

Prema, D. 2013. Site selection and water quality in mariculture: CMFRI manuel customized training book. Karala. Central Marine Fisheries Research Institute. 36-39 pp.

Radiarta, I., S.E. Wardoyo, B. Priyono, dan O.Praseno. 2003. Aplikasi sistem informasi geografis untuk penentuan lokasi pengembangan budidaya laut di Teluk Ekas, Nusa Tenggara Barat. J. Penelitian Perikanan Indonesia, 9(1):67-71.

Redmond,S., L. Green, C. Yarish, J. Kim, and C. Neefus. 2014. New England seaweed culture handbook-nursery systems. Connecticut Sea Grant CTSG-14-01: 92.

Rees WE. 1996. Revisiting carrying capacity: area-based indicators of sustainability. $J$ Population and Environment, (17):195-215.

Setiyanto ,D., I. Efendi, dan K.J. Antara. 2008. Pertumbuhan Kappaphycus alvarezii var Maumare, var Sacol dan Eucheuma cottonii di Perairan Musi Buleleng. J. Ilmu Kelautan, 13(3):171-176.

Tee, M.Z., Y.S. Yong, K.F. Rodrigues, and W.T.L. Yong. 2015. Growth 
rate analysis and protein identification of Kappaphycus alvarezii (Rhodophyta, Gigartinales) under $\mathrm{pH}$ induced stress culture. J.Aquaculture Reports, 2:112-116.

[UNEP] United Nations Environment Programme. 1999. Carrying capacity assessment for tourism development. Coastal Area Management Programme (CAMP). FUKA-MATROUH. Egypt. 4p.

Widigdo, B., J. Pariwono. 2003. Daya dukung perairan di pantai utara Jawa Barat untuk budidaya udang (Studi kasus di Kabupaten Subang, Teluk Jakarta dan Serang). Jurnal
Ilmu-Ilmu Perairan dan Perikanan Indonesia, 1:10-17.

Yong,W.T.L., S.H. Ting, Y.S. Yong, V.Y. Thien, S.H. Wong, W.L. Chin, K.F. Rodrigues, and A. Anton. 2013. Optimization of culture conditions for the direct regeneration of Kappaphycus alvarezii Rhodophyta, Solieriaceae ). J. Appl Phycol, 25(5): DOI 10.1007.

Yonvitner, S.B. Susilo, G. Rakasiwi, dan A.A. Taurusman. 2007. Daya dukung pulau-pulau kecil dengan pendekatan ekological footprint : Kasus di Pulau Wetar. Bogor. PKSPL IPB. 12Hlm. 